SoTEL Symposium 19-20 February 2020

\title{
Creating blended learning experiences requires more than digital skills
}

\author{
Bettina Schwenger \\ University of Auckland \\ bettina.schwenger@gmail.com
}

Submission Type: Brief Presentation (20mins + 10minsQ\&A)

Keywords: staff development, blended learning design, digital literacies.

\section{Abstract}

With growing diversity and larger numbers of enrolled students in classes, online learning can open up new possibilities in New Zealand's tertiary institutions to improve teaching and enhance students' learning. Tertiary institutions have reacted with changed expectations about pedagogical approaches and practices, by, for example, integrating more online learning technologies, and by reconsidering the course design and learning environment (Conole, 2016; Johnson, Adams Becker, Estrada \& Freeman, 2015). Consequently, teachers increasingly teach online as part of a course and need to engage large number of students with a broad range of skills and knowledge, including many who are first in their family to learn formally at tertiary level.

Teachers may work with certain areas of online technologies and digital literacies, for example deposit information online for students to read, but they often do not feel confident to facilitate active learning (Ako \& Synapsys, 2018; Boelens, de Wever \& Voet, 2017) and to offer tasks that aim to engage students collaboratively online. Kirkwood (2014) points out that teachers question how an online tool can be used but may consider less the rationale for the use of a certain pedagogical strategy for which a tool could be used. Digital literacies are more than gaining isolated technological skills (Johnson et al., 2015) as this presentation will share, based on the findings of a collaboration with two teachers in a first-year undergraduate course in Education. In the presentation, we will discuss recommendations for sustainable teacher development that enable blended learning design with opportunities for students to actively create instead of consuming information and that is likely to enhance their experiences of blended learning. The recommendations include underpinning skills and areas such as supporting learning for Māori and non-Māori students by using online affordances for pedagogical practices to, for example, integrate formative feedback, self-assessment, foster active learning online and independent learning.

\section{References}

Ako Aotearoa \& Synapsys (2018). Technology in learning: Benchmarking and developing sector capability. Wellington, New Zealand: Ako Aotearoa

Boelens, R., De Wever, B., \& Voet, M. (2017). Four key challenges to the design of blended learning: A systematic literature review. Educational Research Review, 22, 1-18. doi:10.1016/j.edurev.2017.06.001

Conole, G. (2016). Theoretical underpinnings of learning design. In J. Dalziel (Ed.), Learning design: Conceptualizing a framework for teaching and learning online (pp. 42-62). New York, NY: Routledge.

Johnson, L., Adams Becker, S., Estrada, V., \& Freeman, A. (2015). NMC Horizon report: 2015 Higher education edition. Austin, TX: The New Media Consortium. Retrieved from https://www.nmc.org/publication/nmc-horizon-report-2015-higher-education-edition/

Kirkwood, A. (2014). Teaching and learning with technology in higher education: Blended and distance education needs 'joined-up thinking' rather than technological determinism. Open Learning, 29(3), 206-221. 